\title{
Synthesis and crystal structure determination of $\mathrm{Br}_{2} \mathrm{SeIBr}$ polyhalogen-chalcogen
}

\author{
A A ALEMI* and E SOLAIMANi ${ }^{\dagger}$ \\ Department of Inorganic Chemistry, Faculty of Chemistry, University of Tabriz, Iran \\ ${ }^{\dagger}$ Department of Chemistry, Faculty of Science, University of Shahrood, Shahrood, Iran \\ MS received 4 July 2003; revised 19 January 2004
}

\begin{abstract}
In this paper polyhalogen-chalcogen $\mathrm{Br}_{2} \mathrm{SeIBr}$ was synthesized and the crystal structure was determined by single crystal $X$-ray diffraction method. This compound was prepared in the temperature range $150-50^{\circ} \mathrm{C}$ which was brownish-red in colour and crystallized in monoclinic crystal system and space group $P 2_{1 / c}$ with four molecules per unit cell. Lattice parameters were: $a=6 \cdot 3711(1), b=6 \cdot 7522(2), c=16 \cdot 8850(5) \AA$, $\alpha=\gamma=90^{\circ}, \beta=95.96^{\circ}, \nu=722 \cdot 45 \AA^{3}$.
\end{abstract}

Keywords. Se; polyhalogen; chalcogen.

\section{Introduction}

For a long time, the multi-element compounds of main group elements were prepared and studied. The preparation of polyhalogen and polyhalogen-chalcogen compounds with different structural modifications which were the same as multi-element compounds of main group elements, were studied by most inorganic chemists. The preparation and study of $\mathrm{S}_{2} \mathrm{I}_{4}\left(\mathrm{MF}_{6}\right)_{2},(\mathrm{M}=\mathrm{As}, \mathrm{Sb})$ (Murchie et al 1992), $\mathrm{Se}_{2} \mathrm{I}_{4}\left(\mathrm{AsF}_{6}\right)_{2} \cdot \mathrm{SO}_{2}$ and the electronic structures of the eclipsed diselenium tetraiodide $(2+)$ cation, containing two $\mathrm{SeI}_{2}^{+}$(Nandana et al 1982) and the study of $\mathrm{Te}_{6} \mathrm{I}_{2}^{+}$cation in $\mathrm{Te}_{6} \mathrm{I}_{2}\left(\mathrm{WCl}_{6}\right)_{2}\left(\right.$ Beck 1995), $\left[\mathrm{Se}_{6} \mathrm{I}\right]_{n}^{+}$in $\left[\mathrm{Se}_{6} \mathrm{I}\right]_{n} \cdot n\left[\mathrm{MF}_{6}\right](\mathrm{M}=\mathrm{As}, \mathrm{Sb})$ (Nandana et al 1990) as polymeric cations of halogen-chalcogen and their crystallographic investigation prompted us to study the reaction of halogen and chalcogen group elements.

\section{Experimental}

\subsection{Preparation of $\mathrm{SeBr}_{4}$}

Se powder and bromine were purchased from Merck company and $\mathrm{SeBr}_{4}$ was prepared from the reaction of $\mathrm{Se}$ powder $(0.1 \mathrm{~g})$ with $\mathrm{Br}_{2}(0.41 \mathrm{~g})$ in a sealed ampoule glass of $20 \mathrm{~cm}$ length and $1.5 \mathrm{~cm}$ diameter in horizontal furnace at $80^{\circ} \mathrm{C}$, after two days of heating the yellow crystals of $\mathrm{SeBr}_{4}$ were found in the cold end of glass tube. All compounds were handled in argon filled glove box.

\subsection{Preparation of $\mathrm{Br}_{2} \mathrm{SeIBr}$}

Selenium $(0 \cdot 222 \mathrm{~g}), \operatorname{SeBr}_{4}(1 \cdot 12 \mathrm{~g})$ and iodine $(1.424 \mathrm{~g})$ were filled in a glass ampoule of $25 \mathrm{~cm}$ length and $1.5 \mathrm{~cm}$

\footnotetext{
*Author for correspondence
}

diameter and heated in a horizontal tube furnace with a temperature gradient of $150-50^{\circ} \mathrm{C}$ after evacuation and sealing off the ampoule, for obtaining a good crystallization, at first the ampoule was heated for $5 \mathrm{~h}$ at $150^{\circ} \mathrm{C}$, then we applied the temperature gradient as $\left(0.04^{\circ} \mathrm{C} / \mathrm{min}\right)$ to $100^{\circ} \mathrm{C}$ by heating for $48 \mathrm{~h}$ in such temperature, we also applied the other temperature gradient as $\left(0.01^{\circ} \mathrm{C} / \mathrm{min}\right)$ to $50^{\circ} \mathrm{C}$. After $120 \mathrm{~h}$ heating in $50^{\circ} \mathrm{C}$, we found brownish-red colour crystals of $\mathrm{Br}_{2} \mathrm{SeIBr}$ in the cold end port of the ampoule.

\section{$2.3 \quad X$-ray diffraction}

$\mathrm{X}$-ray diffraction measurements were performed with $\mathrm{Cu}$ $\mathrm{K} \alpha$ radiation on a Rigaku Multiflex diffractometer equipped with a curved graphite monochromator. Intensity data were collected by step scanning in the range of $2-90^{\circ}$ at intervals of $0.02^{\circ}$.

\section{Results and discussion}

\subsection{Crystal structure determination}

Single crystal X-ray diffraction analysis of brownish-red crystal shows the crystallization in monoclinic system with space group $P 2_{1 / c}$ and cell constants are: $a=6.3711(1), b=$ 6.7522(1), $c=16.8850(5) \AA, \alpha=\gamma=90^{\circ}, \beta=95.96^{\circ}, z=4$, $v=722.45 \AA^{3}$ and $P_{\mathrm{c}}=4.047 \mathrm{~g} / \mathrm{cm}^{3}$. Table 1 shows the crystal data and crystal refinement of $\mathrm{Br}_{2} \mathrm{SeIBr}$, table 2 shows the atomic coordinates and equivalent isotropic displacement parameters, table 3 shows bond lengths and bond angles of $\mathrm{Br}_{2} \mathrm{SeIBr}$ and table 4 shows anisotropic displacement parameters.

The crystal structure of $\mathrm{Br}_{2} \mathrm{SeIBr}$ molecule is illustrated in figure 1 , as we can find from table 3 the $\operatorname{Br}(1)$ 
Table 1. Crystal data and structure refinement for $\mathrm{Br}_{2} \mathrm{SeIBr}$.

\begin{tabular}{ll}
\hline Identification code & $\mathrm{Br}_{2} \mathrm{SeIBr}$ \\
Empirical formula & $\mathrm{Br}_{3} \mathrm{ISe}$ \\
Formula weight & $445 \cdot 59$ \\
Temperature & $273(2) \mathrm{K}$ \\
Wavelength & $0 \cdot 71073 \AA$ \\
Crystal system, space group & Monoclinic, $P 2_{1 / c}$ \\
Unit cell dimensions & $a=6 \cdot 3711(1) \AA ; \alpha=90^{\circ}$ \\
& $b=6 \cdot 7522(2) \AA ; \beta=95 \cdot 96(2)^{\circ}$ \\
& $c=16 \cdot 8850(5) \AA ; \gamma=90^{\circ}$ \\
Volume & $722 \cdot 45(3) \AA^{3}$ \\
$Z$, calculated density & $4,4 \cdot 097 \mathrm{~kg}^{-} \mathrm{m}^{3}$ \\
Absorption coefficient & $25 \cdot 934 \mathrm{~mm}^{-1}$ \\
$F(000)$ & 768 \\
Crystal size & $0 \cdot 5 \times 0 \cdot 45 \times 0 \cdot 4 \mathrm{~mm}$ \\
$\theta$ range for data collection & $2 \cdot 43-27 \cdot 49^{\circ}$ \\
Limiting indices & $-8 \leq h \leq 7,-8 \leq k \leq 8,-21 \leq l \leq 21$ \\
Reflections collected/unique & $13274 / 1653\left[R_{\text {int }}=0 \cdot 1623\right]$ \\
Completeness to data & up to $\theta=27 \cdot 49^{\circ} 99 \cdot 9 \%$ \\
Refinement method & Full-matrix least-squares on $F^{2}$ \\
Data/restraints/parameters & $1653 / 0 / 47$ \\
Goodness-of-fit on $F^{2}$ & $1 \cdot 086$ \\
Final $R$ indices [1 $>2 \sigma(1)]$ & $R 1=0 \cdot 0412, w R 2=0 \cdot 1088$ \\
$R$ indices (all data) & $R 1=0 \cdot 0466, w R 2=0 \cdot 1131$ \\
Extinction coefficient & $0 \cdot 0122(8)$ \\
Largest diff. peak and hole & $1 \cdot 731$ and $-1 \cdot 687$ e $\AA^{-3}$ \\
\hline
\end{tabular}

Table 2. Atomic coordinates $\left(\times 10^{4}\right)$ and equivalent isotropic displacement parameters $\left(\AA^{2} \times 10^{3}\right)$ for $\mathrm{Br}_{2} \mathrm{SeIBr}$.

\begin{tabular}{lrrrr}
\hline & \multicolumn{1}{c}{$X$} & \multicolumn{1}{c}{$Y$} & $Z$ & $\mathrm{U}(\mathrm{eq})$ \\
\cline { 2 - 5 } $\mathrm{I}$ & $267(1)$ & $1454(1)$ & $3390(1)$ & $34(1)$ \\
$\mathrm{Se}$ & $-3359(1)$ & $3502(1)$ & $3699(1)$ & $33(1)$ \\
$\operatorname{Br}(1)$ & $3852(1)$ & $-413(1)$ & $3145(1)$ & $41(1)$ \\
$\operatorname{Br}(2)$ & $-1642(1)$ & $6495(1)$ & $3938(1)$ & $49(1)$ \\
$\operatorname{Br}(3)$ & $-3547(1)$ & $3885(1)$ & $4990(1)$ & $46(1)$ \\
\hline
\end{tabular}

Table 3. Bond length $[\AA ̊]$ and angles $\left[{ }^{\circ}\right.$ ] for $\mathrm{Br}_{2} \mathrm{SeIBr}$.

\begin{tabular}{lc}
\hline $\mathrm{I}-\mathrm{Br}(1)$ & $2 \cdot 6785(8)$ \\
\hline $\mathrm{I}-\mathrm{Se}$ & $2 \cdot 7879(8)$ \\
$\mathrm{Se}-\mathrm{Br}(2)$ & $2 \cdot 3131(1)$ \\
$\mathrm{Se}-\mathrm{Br}(3)$ & $2 \cdot 3223(1)$ \\
$\mathrm{Br}(1)-\mathrm{I}-\mathrm{Se}$ & $177 \cdot 35(3)$ \\
$\mathrm{Br}(2)-\mathrm{Se}-\mathrm{Br}(3)$ & $100 \cdot 91(4)$ \\
$\operatorname{Br}(2)-\mathrm{Se}-\mathrm{I}$ & $94 \cdot 59(3)$ \\
$\operatorname{Br}(3)-\mathrm{Se}-\mathrm{I}$ & $98 \cdot 00(3)$ \\
\hline
\end{tabular}

I-Se bond angle is $177.35^{\circ}$ and the bond angles around Se atoms are: $100 \cdot 91^{\circ}, 94.59^{\circ}, 98^{\circ}$, for $\operatorname{Br}(2)-\operatorname{Se}-\operatorname{Br}(3)$, I-Se-Br(2), I-Se-Br(3), respectively, so we can estimate that the Se atom surrounded by halogen atoms in pyramidal structure are in close conformity with $\mathrm{Me}_{2} \mathrm{SeIBr}$ and $\mathrm{Ph}_{2} \mathrm{SeIBr}$ (Godfrey et al 1997). Figure 2 shows the molecular structure of $\mathrm{Br}_{2} \mathrm{SeIBr}$ and other bromine atoms from very closed molecules in unit cell. Study of the interactions between Se atoms and all bromine atoms in sphere
Table 4. Anisotropic displacement parameters $\left(\AA^{2} \times 10^{3}\right)$ for $\mathrm{Br}_{2} \mathrm{SeIBr}$. The anisotropic displacement factor exponent takes the form: $2 \pi^{2}\left[h^{2} a^{* 2} U 11+\ldots+2 h k a * b^{*} U 12\right]$.

\begin{tabular}{lrrrrrr}
\hline & U11 & U22 & U33 & U23 & U13 & U12 \\
\cline { 2 - 7 } I & $33(1)$ & $33(1)$ & $36(1)$ & $1(1)$ & $7(1)$ & $0(1)$ \\
Se & $29(1)$ & $34(1)$ & $38(1)$ & $3(1)$ & $7(1)$ & $0(1)$ \\
$\operatorname{Br}(1)$ & $36(1)$ & $48(1)$ & $39(1)$ & $-6(1)$ & $4(1)$ & $8(1)$ \\
$\operatorname{Br}(2)$ & $44(1)$ & $38(1)$ & $65(1)$ & $-6(1)$ & $14(1)$ & $-7(1)$ \\
$\operatorname{Br}(3)$ & $49(1)$ & $54(1)$ & $37(1)$ & $6(1)$ & $11(1)$ & $-4(1)$ \\
\hline
\end{tabular}

of coordination with different distances $(2 \cdot 313 \AA-4 \cdot 172 \AA)$ reveals that the Se atoms were surrounded by six halogen atoms (five bromine and one iodine atoms) as highly distorted octahydral. In between five bromine atoms (except number 3 with bond distance, $4 \cdot 173 \AA$ ), all other atoms are in good agreement with $\mathrm{Se}$ and $\mathrm{Br}$ van der Waals radius (Huheey 1986).

\subsection{Molecular properties}

Table 2 indicates that in $\mathrm{Br}_{2} \mathrm{SeIBr}$ molecule the $\mathrm{I}-\mathrm{Br}$ bond length is $2.678 \AA$, but in a diatomic $\mathrm{IBr}$ molecule the bond is $2.485 \AA$ (Macintyre 1994), so the existence of $0.193 \AA$ difference can be dependent as the electron density distribution between $\mathrm{IBr}$ molecule and $\mathrm{Br}_{2} \mathrm{Se}$ port of $\mathrm{Br}_{2} \mathrm{SeIBr}$ molecule, it means that the electron density could be transferred from Se atom of $\mathrm{Br}_{2} \mathrm{Se}$ part, into $\sigma^{*}$ antibonding orbital of iodine atom of $\mathrm{IBr}$, and the construction of $\mathrm{Br}_{2} \mathrm{SeIBr}$ molecule will be the same as Lewis acidbase adducts, like $\mathrm{Cl}_{2} \mathrm{SeICl}$ (Alemi and Solaimani 2000). 


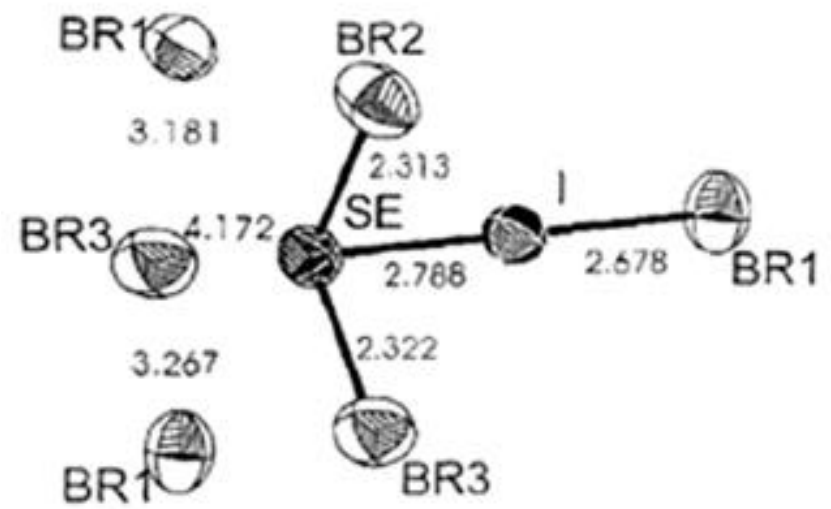

Figure 1. A molecule of $\mathrm{Br}_{2} \mathrm{SeIBr}$ including the coordination sphere of the selenium atom.

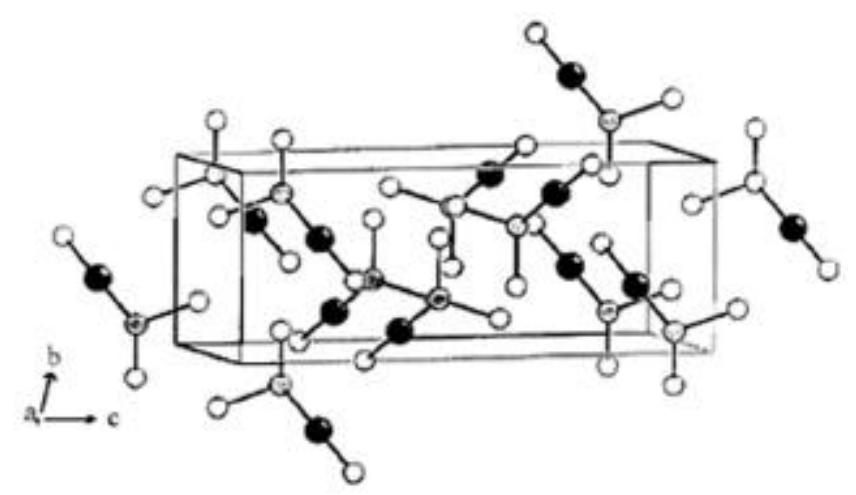

Figure 2. The unit cell of $\mathrm{Br}_{2} \mathrm{SeIBr}$.

Table 5. Bond lengths $[\AA ̊]$ and angles $\left[{ }^{\circ}\right]$ for some polyhalogens-chalcogens.

\begin{tabular}{lccl}
\hline Formula & Se-I & I-Br & Se-Br \\
\hline $\mathrm{Br}_{2} \mathrm{SeIBr}$ & $2 \cdot 788$ & $2 \cdot 678$ & 177 \\
$\mathrm{Me}_{2} \mathrm{SeIBr}$ & $2 \cdot 797$ & $2 \cdot 664$ & $175 \cdot 8$ \\
$\mathrm{Ph}_{2} \mathrm{SeIBr}$ & $2 \cdot 809$ & $2 \cdot 640$ & $177 \cdot 29$ \\
$\mathrm{C}_{8} \mathrm{H}_{7} \mathrm{NSSeIBr}$ & $2 \cdot 814$ & $2 \cdot 633$ & $177 \cdot 9$ \\
\hline
\end{tabular}

Table 5 shows the bond lengths and bond angles of $\mathrm{Br}_{2} \mathrm{SeIBr}$ and some other polyhalogen-chalcogen derivatives and in column one, we find the Se-I bond lengths increasing from top to bottom, but in column two the bond lengths decrease from top to bottom, although the $\mathrm{Se}-\mathrm{I}-\mathrm{Br}$ bond angles are approximately very close to $180^{\circ}$, but in $\mathrm{Br}_{2} \mathrm{SeIBr}$ molecule the interaction between $\mathrm{Br}_{2} \mathrm{Se}$ and $\mathrm{IBr}$ will be the same as lewis base and lewis acid adducts. The study of such kind of interaction in other polyhalogen-chalcogen shows the existence of a good relation between base strength of $\mathrm{Br}_{2} \mathrm{Se}, \mathrm{Me}_{2} \mathrm{~S}, \mathrm{Ph}_{2} \mathrm{Se}$, $\mathrm{C}_{8} \mathrm{H}_{7} \mathrm{NSSe}$ for acid-base adducts in polyhalogenchalcogen formation (Godfrey et al 1997). Investigation of $\mathrm{Br}_{2} \mathrm{SeIBr}$ shows its close similarity to $\mathrm{Cl}_{2} \mathrm{SeICl}$ (Alemi and Solaimani 2000) molecule that was recently prepared by our research group, and is also air sensitive and quickly change to opaque colour. Study of its colour change shows a complete deformation of its molecular structure, furthermore its solubility in organic solvents such as $\left(\mathrm{CH}_{2} \mathrm{Cl}_{2}, \mathrm{CHCl}_{3}, \mathrm{CCl}_{4}\right)$ were examined, but in the presence of water it quickly dissociated to $\mathrm{Br}^{-}, \mathrm{SeO}_{2}$, I, etc.

\subsection{Elemental analysis}

Energy dispersion X-ray analysis of $\mathrm{Br}_{2} \mathrm{SeIBr}$ molecule shows the bromine content as $18.2 \%$, selenium as $24 \cdot 14 \%$ and iodine as $54.53 \%$.

\section{Conclusions}

It is concluded that the polyhalogen-chalcogen $\mathrm{Br}_{2} \mathrm{SeIBr}$ with halogen character could be prepared at low temperature. Bond angle measurements show the $\mathrm{Se}-\mathrm{I}-\mathrm{Br}$ bond angle to be close to $180^{\circ}$ and could estimate the presence of lewis base and lewis acid adducts in this compound.

\section{Acknowledgements}

The authors acknowledge the financial support from the Council of Tabriz University, Iran.

\section{References}

Alemi A A and Solaimani E 2000 Iranian J. Crystal-Mineral. 8 151

Beck J 1995 J. Chem. Ber. 12823

Godfrey S M, MC-Auliffer C A, Pritchard R G and Sarwar S 1997 J. Chem. Soc. Dalton Trans 6501

Huheey J E 1986 Inorganic chemistry (New York: Harper collins) 3rd ed. p. 209

Macintyre J E 1994 Dictionary of inorganic compounds (London, New York, Tokyo: Chapman and Hall) Vol. 1, p. 295

Murchie M P, Johnson J P, Passmore J, Sutherland G W, Tajik M, Whidden T K, White P S and Grein F 1992 Inorg. Chem. 31274

Nandana W A S, Passmore J, White P S and Wang Chi-Ming 1982 J. Chem. Soc. Chem. Commun. 1098

Nandana W A S, Passmore J, White P S and Wong Chi-Ming 1990 Inorg. Chem. 293529 